\title{
Global \& Community Health: Implementation of and Patient Satisfaction With the First Neurologic Telemedicine Program in Mexico During COVID-19
}

Rogelio Domínguez-Moreno, MD, * Miguel García-Grimshaw, MD,* Oswaldo Alan Chávez-Martínez, MD, Daniel Rebolledo-García, MD, Jarumi Crystal Diestel-Bautista, MD, Anaclara Michel-Chávez, MD, Juan Andrés Calderón-Martínez, MD, Dioselina Panamá Tristán-Samaniego, MD, Alma Vigueras-Hernández, MD, Humberto Estrada-Rodríguez, MD, Felipe Arturo Vega-Boada, MD, Luis Dávila-Maldonado, MD, Miguel Ángel Tanimoto, MD, Carlos Cantú-Brito, MD, PhD, and Alejandra González-Duarte, MD*

Neurology ${ }^{\circledR} 2021 ; 97: 293-296$. doi:10.1212/WNL.0000000000012291

Due to the large number of patients requiring in-hospital care during the coronavirus disease 2019 (COVID-19) pandemic outbreak, hospitals worldwide were converted into COVID-19 referral centers. In addition to social distancing and mandatory use of face masks, other measures to reduce the risk of infection among health care workers included increasing the time between work shifts and sending high-risk personnel to in-home isolation. This resulted in a significantly reduced workforce, requiring relocation of medical personnel from multiple specialties to the frontline. ${ }^{1,2}$ Due to staff shortage, many Mexican hospitals had to reduce the number of non-COVID-19 face-to-face consultations. ${ }^{2,3}$ Across multiple specialties-including neurology-telemedicine proved to be an effective outpatient follow-up method ${ }^{4}$ as it satisfied public health mitigation strategies by increasing social distancing and reducing mobility. ${ }^{5,6}$ Furthermore, it helped clinicians track patients' follow-up and detect those who may need an inperson evaluation or acute in-hospital management. ${ }^{4,7}$ We describe our experience in developing and implementing a teleneurology program in Mexico.

\section{Methods}

This exploratory study was conducted at the Instituto Nacional de Ciencias Médicas y Nutrición Salvador Zubirán, a third-level teaching hospital in Mexico City that was converted into a COVID-19 referral center in March 2020. Local ethics and research committees approved the study (NER-3618-20-20-1). Usually, our center provides approximately 800 monthly follow-up general neurology consultations in a resident-led continuity clinic, supervised by 2 attending neurologists. By April 2020, due to the reduction of medical and administrative staff in addition to the steadily increasing number of patients, our center authorities stopped all face-to-face non-COVID-19 consultations. We adapted to the challenges and started researching how to implement a teleneurology program to reopen our continuity clinic (figure 1).

\section{Program Implementation}

By the end of May, we began training on how to perform a virtual neurologic examination (VNE). ${ }^{\mathrm{e} 1, \mathrm{e} 2}$ Due to our populations' characteristics, where many patients have limited or no access to an in-home computer with Internet connection, one of the initial problems we faced was deciding which platform to use. To solve this, we conducted several telephonic and videocall surveys with the patients who were originally scheduled for a follow-up visit during the last week of May. We offered them and tested 3 different platforms (Zoom, Doxy.me, and WhatsApp). Based on those results, we concluded that WhatsApp was the most available and user-friendly platform for our population, despite the limitations imposed by cellphones'
Correspondence

Dr. Domínguez-Moreno

rogelio_dm@hotmail.com
MORE ONLINE

COVID-19 Resources

For the latest articles, invited commentaries, and blogs from physicians around the world

NPub.org/COVID 19

\footnotetext{
*These authors contributed equally to this work as co-first authors.
}

From the Department of Neurology and Psychiatry (R.D.-M., M.G.-G., O.A.C.-M., D.R.-G., J.C.D.-B., A.M.-C., J.A.C.-M., D.P.T.-S., A.V.-H., H.E.-R., F.A.V.-B., L.D.-M., C.C.-B., A.G.-D.) and Telemedicine Unit (M.Á.T.), Instituto Nacional de Ciencias Médicas y Nutrición Salvador Zubirán, Mexico City, Mexico.

Go to Neurology.org/N for full disclosures. Funding information and disclosures deemed relevant by the authors, if any, are provided at the end of the article. 


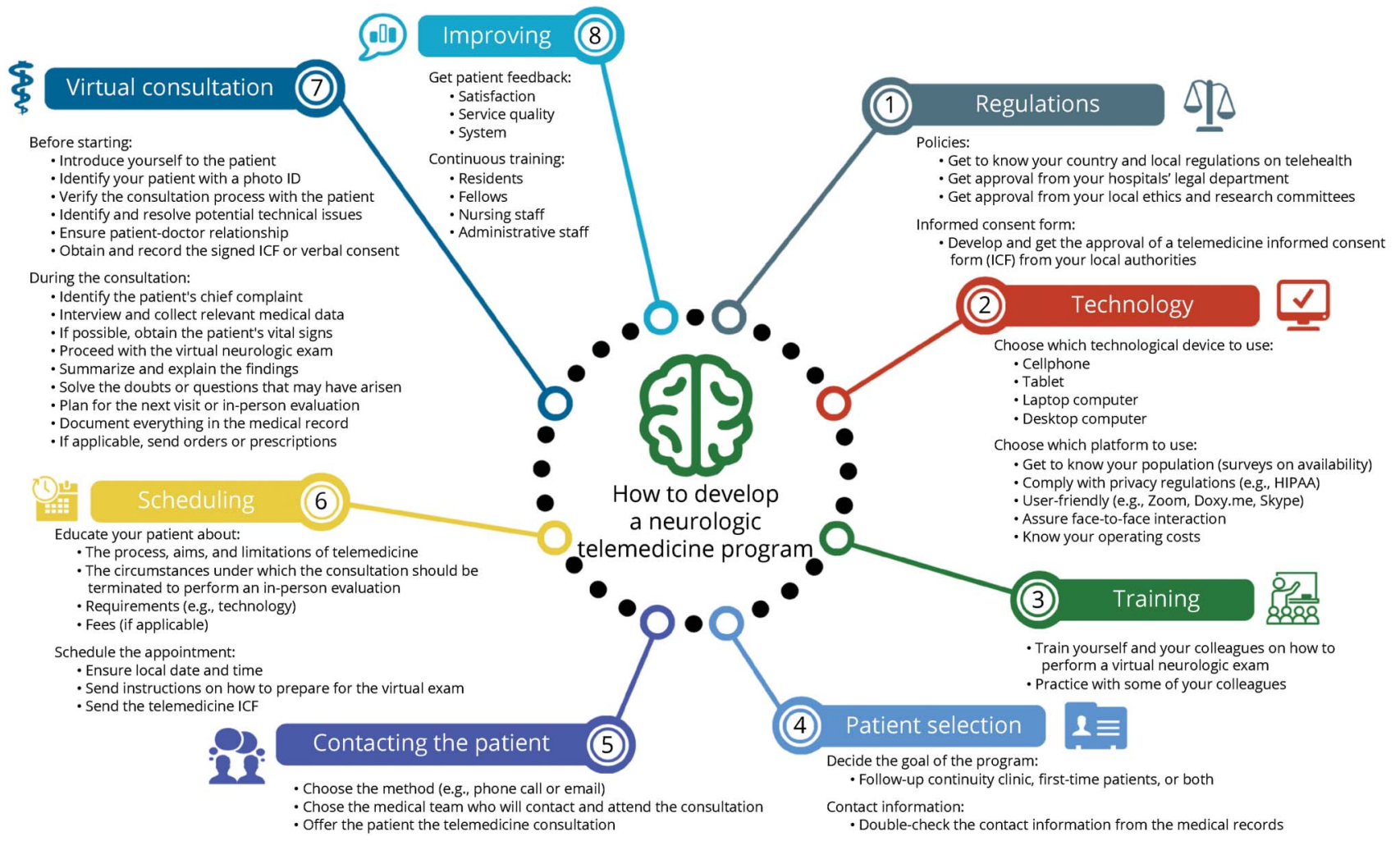

Figure created by M.G.-G. using venngage.com. HIPAA = Health Insurance Portability and Accountability Act.

narrow screen size and camera angle. Another problem was that in approximately $50 \%$ of patients, contact data had not been updated on their electronic medical records (EMRs). We were unable to contact them. Furthermore, some patients did not have smartphones or Internet access. After consulting and obtaining permission from our institution's legal department, we decided to provide telephonic consultations in such cases. As our program was starting, the ethics committee and legal department only allowed us to schedule follow-up patients.

One week before starting the program, due to administrative personnel shortage, the neurology residents started contacting patients who were already scheduled for a consultation to reschedule a teleneurology appointment. After describing the telemedicine process, we sent and asked them to sign and send us back an informed consent form (ICF) that we uploaded to the EMR. This ICF included information regarding privacy, potential benefits, and limitations of teleneurology and conditions under which consultations should be terminated to perform an inperson evaluation, such as a new or rapidly progressing neurologic condition requiring acute care. For those patients for whom the consultation was telephonic, we asked for their verbal consent and documented it on the EMR before starting the consultation.

On July 6, 2020, using 3 smartphones provided by neurology department personnel, we started our program with a monthly cost of approximately $\$ 35$, used for all smartphones' data plans (figure e-1, available from Dryad, doi.org/10.5061/ dryad.tqjq2bvxg). To assess patient satisfaction and quality of the health care received, at the end of the consultations, to those who had Internet access, we sent via email or text message an anonymous 24-question online-based questionnaire (modified for the COVID-19 pandemic) developed and validated for the Spanish-speaking population (tables e-1 and $\mathrm{e}-2$, available from Dryad). ${ }^{\text {e3 }}$

\section{Results}

From July 6 to September 30, 2020, 322 patients were scheduled. For this report, we excluded 18 patients (14 did not answer the video calls, and in 4 the appointment was cancelled). We included 304 patients (233 [76.6\%] women, mean age $52.8+16.9$ years); 29 (8.5\%) were telephonic consultations. The most common neurologic disorders we attended were neuromuscular disorders in 102 (33.6\%) patients, headache disorders in 100 (32.9\%), epilepsy in 35 (11.5\%), cerebrovascular diseases in 18 (5.9\%), and movement disorders in 17 (5.6\%). Table e-3 (available from Dryad, doi.org/10.5061/dryad.tqjq2bvxg) includes a detailed list of all the evaluated neurologic disorders. None of the patients required acute in-hospital care. Only 2 $(0.66 \%)$ patients required in-person evaluations due to suspected progression of polyneuropathy. 
Of the 304 patients, only 125 (41\%) answered the survey; 108 (86.4\%) preferred teleneurology instead of an in-person consultation, $83.3 \%(90 / 108)$ of them because of concerns about getting COVID-19. A total of 115 (92\%) patients completely agreed that they felt comfortable when talking to the neurologist through a camera and a microphone, and 120 (96\%) reported being satisfied with their consultation; 5 (4\%) were not satisfied, but their reasons were not specified; 109 $(87.2 \%)$ completely agreed that they trusted that their privacy would be protected. Table e-4 (available from Dryad, doi.org/ 10.5061/dryad.tqjq2bvxg) describes all responses.

\section{Discussion}

As of March 8, 2021, with 2.1 million confirmed cases (11\% of them among health care workers) and more than 190,000 deaths, Mexico had the third-highest number of deaths and active cases globally, just behind the United States and Brazil. ${ }^{\mathrm{e}, 5}$ Only $0.48 \%$ of our population had been fully vaccinated at that time. ${ }^{\mathrm{e} 6}$ The impact of the COVID-19 pandemic on outpatient visits and its long-term consequences are unknown. ${ }^{\mathrm{e} 7,8}$

In response to the pandemic, the use of telemedicine has increased worldwide. ${ }^{5,6,8}$ In neurology, the strongest evidence supporting its use derives from experience in managing acute ischemic stroke, where it has proven to be as effective as an inperson evaluation. Currently, due to limited evidence, teleneurology is mainly recommended as a follow-up method for a few neurologic conditions, including nonacute headache disorders, where there is evidence proving that teleneurology is as useful as an in-person evaluation; other diseases include epilepsy, multiple sclerosis, dementia, and neuromuscular and movement disorders. ${ }^{4}$

Although it is possible to perform a reliable VNE, making feasible the use of teleneurology for new patients, there may be conditions requiring in-person visits, especially those needing a comprehensive eye examination, assessment of the vestibular system, and examination of muscle tone, reflexes, and sensory testing. ${ }^{4,6,9}$ If combined with some well-known red flags, teleneurology could be an effective method to triage patients requiring acute care. ${ }^{4}$ Teleneurology offers many benefits for both patients and health care providers, including expediting care, continuous monitoring of chronic conditions, and follow-up after hospitalization. It also increases access to a neurologist, especially for patients with limited mobility and those traveling long distances to attend their visits, reducing patient costs. ${ }^{4-6}$ Furthermore, reducing the number of face-toface consultations may help mitigate the pandemic by maintaining social distancing and reducing social mobility, particularly for those more vulnerable to COVID-19. ${ }^{5,7,9}$

In Mexico, according to a global survey conducted by the Telemedicine Study Group of the Movement Disorders Society, the Movement Disorders Clinic of the National Institute of Neurology and Neurosurgery in Mexico City has started using telemedicine using Cisco Webex as its platform. Their results and experiences are yet to be reported. ${ }^{8}$ As reported in a position paper by the COVID-19 Pandemic Health System Resilience Program consortium, in Latin America and especially in Mexico, there are many legislative, economic, and technological challenges to overcome in order for telemedicine to reach its full potential. ${ }^{10}$ Unlike in the United States, where telehealth is subject to HIPAA (Health Insurance Portability and Accountability Act) rules, there are no specific regulations on telehealth in Mexico. ${ }^{\text {e9-e11 }}$ Nonetheless, its use is encouraged by the Mexican Ministry of Health in its General Health Law. ${ }^{\text {e12 }}$

In December 2020, 6 months after starting the program, our center launched an institutional Web-based telemedicine platform called CONEcTA to standardize and regulate the service. ${ }^{\text {el3 }}$ Throughout this process, we have learned that there are many challenges to overcome. Mexico has an urgent need to develop specific legislation regarding telehealth, expand technology access to remote locations, and increase telemedicine awareness and adoption among clinicians. In our center and as neurology trainees, we learned how to implement a teleneurology program with limited resources to keep caring for our patients. How to perform a virtual neurologic examination adapted to our population and the need for continuous improvement and training for our administrative personnel, nursing staff, and our programs' current and upcoming residents are important areas of research.

Our study has several limitations. First, as we were not allowed to include new patients and owing to the low percentage of survey respondents, our satisfaction and quality results may be biased. Second, we did not assess provider satisfaction and limitations during the consultation. Third, the small number of cases compared to our usual number of visits may overestimate our results; however, this was an exploratory study proposed by neurology residents to reopen our outpatient clinic to provide medical care and to continue with our training.

We described our experience developing and implementing a low-cost teleneurology program with many improvement opportunities, but so far with good results. At the time we submitted this manuscript, this is the first Mexican report describing the implementation of telemedicine in a general neurology continuity clinic. As illustrated in the flowchart (figure 1), this program may be easy to reproduce in other developing countries depending on their laws. We hope that our experience may assist neurology residents and fellows from other developing countries in designing and adopting a teleneurology program.

\section{Study Funding}

The authors report no targeted funding.

\section{Disclosure}

The authors report no disclosures. Go to Neurology.org/N for full disclosures. 
Appendix Authors

\begin{tabular}{|c|c|c|}
\hline Name & Location & Contribution \\
\hline $\begin{array}{l}\text { Rogelio } \\
\text { Domínguez- } \\
\text { Moreno, MD }\end{array}$ & $\begin{array}{l}\text { Instituto Nacional de } \\
\text { Ciencias Médicas y } \\
\text { Nutrición Salvador Zubirán, } \\
\text { Mexico City, Mexico }\end{array}$ & $\begin{array}{l}\text { Designed and } \\
\text { conceptualized study, } \\
\text { collected and analyzed the } \\
\text { data, drafted and reviewed } \\
\text { the manuscript for } \\
\text { intellectual content }\end{array}$ \\
\hline $\begin{array}{l}\text { Miguel García- } \\
\text { Grimshaw, MD }\end{array}$ & $\begin{array}{l}\text { Instituto Nacional de } \\
\text { Ciencias Médicas y } \\
\text { Nutrición Salvador Zubirán, } \\
\text { Mexico City, Mexico }\end{array}$ & $\begin{array}{l}\text { Designed and } \\
\text { conceptualized study, } \\
\text { collected and analyzed the } \\
\text { data, drafted and reviewed } \\
\text { the manuscript for } \\
\text { intellectual content }\end{array}$ \\
\hline $\begin{array}{l}\text { Oswaldo Alan } \\
\text { Chávez- } \\
\text { Martínez, MD }\end{array}$ & $\begin{array}{l}\text { Instituto Nacional de } \\
\text { Ciencias Médicas y } \\
\text { Nutrición Salvador Zubirán, } \\
\text { Mexico City, Mexico }\end{array}$ & $\begin{array}{l}\text { Collected and analyzed the } \\
\text { data, reviewed the } \\
\text { manuscript for intellectual } \\
\text { content }\end{array}$ \\
\hline $\begin{array}{l}\text { Daniel } \\
\text { Rebolledo- } \\
\text { García, MD }\end{array}$ & $\begin{array}{l}\text { Instituto Nacional de } \\
\text { Ciencias Médicas y } \\
\text { Nutrición Salvador Zubirán, } \\
\text { Mexico City, Mexico }\end{array}$ & $\begin{array}{l}\text { Collected and analyzed the } \\
\text { data, reviewed the } \\
\text { manuscript for intellectual } \\
\text { content }\end{array}$ \\
\hline $\begin{array}{l}\text { Jarumi Crystal } \\
\text { Diestel- } \\
\text { Bautista, MD }\end{array}$ & $\begin{array}{l}\text { Instituto Nacional de } \\
\text { Ciencias Médicas y } \\
\text { Nutrición Salvador Zubirán, } \\
\text { Mexico City, Mexico }\end{array}$ & $\begin{array}{l}\text { Collected and analyzed the } \\
\text { data, reviewed the } \\
\text { manuscript for intellectual } \\
\text { content }\end{array}$ \\
\hline $\begin{array}{l}\text { Anaclara } \\
\text { Michel-Chávez, } \\
\text { MD }\end{array}$ & $\begin{array}{l}\text { Instituto Nacional de } \\
\text { Ciencias Médicas y } \\
\text { Nutrición Salvador Zubirán, } \\
\text { Mexico City, Mexico }\end{array}$ & $\begin{array}{l}\text { Collected and analyzed the } \\
\text { data, reviewed the } \\
\text { manuscript for intellectual } \\
\text { content }\end{array}$ \\
\hline $\begin{array}{l}\text { Juan Andrés } \\
\text { Calderón- } \\
\text { Martínez, MD }\end{array}$ & $\begin{array}{l}\text { Instituto Nacional de } \\
\text { Ciencias Médicas y } \\
\text { Nutrición Salvador Zubirán, } \\
\text { Mexico City, Mexico }\end{array}$ & $\begin{array}{l}\text { Collected and analyzed the } \\
\text { data, reviewed the } \\
\text { manuscript for intellectual } \\
\text { content }\end{array}$ \\
\hline $\begin{array}{l}\text { Dioselina } \\
\text { Panamá } \\
\text { Tristán- } \\
\text { Samaniego, MD }\end{array}$ & $\begin{array}{l}\text { Instituto Nacional de } \\
\text { Ciencias Médicas y } \\
\text { Nutrición Salvador Zubirán, } \\
\text { Mexico City, Mexico }\end{array}$ & $\begin{array}{l}\text { Collected and analyzed the } \\
\text { data, reviewed the } \\
\text { manuscript for intellectual } \\
\text { content }\end{array}$ \\
\hline $\begin{array}{l}\text { Alma Vigueras- } \\
\text { Hernández, MD }\end{array}$ & $\begin{array}{l}\text { Instituto Nacional de } \\
\text { Ciencias Médicas y } \\
\text { Nutrición Salvador Zubirán, } \\
\text { Mexico City, Mexico }\end{array}$ & $\begin{array}{l}\text { Collected and analyzed the } \\
\text { data, reviewed the } \\
\text { manuscript for intellectual } \\
\text { content }\end{array}$ \\
\hline $\begin{array}{l}\text { Humberto } \\
\text { Estrada- } \\
\text { Rodriguez, MD }\end{array}$ & $\begin{array}{l}\text { Instituto Nacional de } \\
\text { Ciencias Médicas y } \\
\text { Nutrición Salvador } \\
\text { Zubirán, Mexico City, } \\
\text { Mexico }\end{array}$ & $\begin{array}{l}\text { Collected and analyzed the } \\
\text { data, reviewed the } \\
\text { manuscript for intellectual } \\
\text { content }\end{array}$ \\
\hline
\end{tabular}

Appendix (continued)

\begin{tabular}{|c|c|c|}
\hline Name & Location & Contribution \\
\hline $\begin{array}{l}\text { Felipe Arturo } \\
\text { Vega-Boada, } \\
\text { MD }\end{array}$ & $\begin{array}{l}\text { Instituto Nacional de } \\
\text { Ciencias Médicas y } \\
\text { Nutrición Salvador Zubirán, } \\
\text { Mexico City, Mexico }\end{array}$ & $\begin{array}{l}\text { Collected and analyzed the } \\
\text { data, reviewed the } \\
\text { manuscript for intellectual } \\
\text { content }\end{array}$ \\
\hline $\begin{array}{l}\text { Luis Dávila- } \\
\text { Maldonado, } \\
\text { MD }\end{array}$ & $\begin{array}{l}\text { Instituto Nacional de } \\
\text { Ciencias Médicas y } \\
\text { Nutrición Salvador Zubirán, } \\
\text { Mexico City, Mexico }\end{array}$ & $\begin{array}{l}\text { Collected the data, } \\
\text { reviewed the manuscript } \\
\text { for intellectual content }\end{array}$ \\
\hline $\begin{array}{l}\text { Miguel Ángel } \\
\text { Tanimoto, MD }\end{array}$ & $\begin{array}{l}\text { Instituto Nacional de } \\
\text { Ciencias Médicas y } \\
\text { Nutrición Salvador Zubirán, } \\
\text { Mexico City, Mexico }\end{array}$ & $\begin{array}{l}\text { Collected the data, } \\
\text { reviewed the manuscript } \\
\text { for intellectual content }\end{array}$ \\
\hline $\begin{array}{l}\text { Carlos Cantú- } \\
\text { Brito, MD, PhD }\end{array}$ & $\begin{array}{l}\text { Instituto Nacional de } \\
\text { Ciencias Médicas y } \\
\text { Nutrición Salvador Zubirán, } \\
\text { Mexico City, Mexico }\end{array}$ & $\begin{array}{l}\text { Designed and } \\
\text { conceptualized study, } \\
\text { analyzed the data, drafted } \\
\text { and reviewed the } \\
\text { manuscript for intellectual } \\
\text { content }\end{array}$ \\
\hline $\begin{array}{l}\text { Alejandra } \\
\text { González- } \\
\text { Duarte, MD }\end{array}$ & $\begin{array}{l}\text { Instituto Nacional de } \\
\text { Ciencias Médicas y } \\
\text { Nutrición Salvador Zubirán, } \\
\text { Mexico City, Mexico }\end{array}$ & $\begin{array}{l}\text { Designed and } \\
\text { conceptualized study, } \\
\text { analyzed the data, drafted } \\
\text { and reviewed the } \\
\text { manuscript for intellectual } \\
\text { content }\end{array}$ \\
\hline
\end{tabular}

\section{References}

1. Bielicki JA, Duval X, Gobat N, et al. Monitoring approaches for health-care workers during the COVID-19 pandemic. Lancet Infect Dis. 2020;20(10):e261-e267.

2. Fowler Z, Moeller E, Roa L, et al. Projected impact of COVID-19 mitigation strategies on hospital services in the Mexico City metropolitan area. PLoS One. 2020;15(11):e241954

3. Secretaría de Salud de México. Lineamientos de reconversión hospitalaria [online]. Accessed April 20, 2020. Available at: coronavirus.gob.mx/wp-content/uploads/ 2020/04/Documentos-Lineamientos-Reconversion-Hospitalaria.pdf.

4. Hatcher-Martin JM, Adams JL, Anderson ER, et al. Telemedicine in neurology: Telemedicine Work Group of the American Academy of Neurology update. Neurology. 2020;94(1):30-38

5. Klein BC, Busis NA. COVID-19 is catalyzing the adoption of teleneurology. Neurology. 2020;94(21):903-904.

6. Strowd RE, Strauss L, Graham R, et al. Rapid implementation of outpatient teleneurology in rural Appalachia: barriers and disparities. Neurol Clin Pract. Epub 2020 Jul 13.

7. McGinley MP, Ontaneda D, Wang Z, et al. Teleneurology as a solution for outpatient care during the COVID-19 pandemic. Telemed J E Health. 2020;26(12):1537-1539.

8. Hassan A, Mari Z, Gatto EM, et al. Global survey on telemedicine utilization for movement disorders during the COVID-19 pandemic. Mov Disord. 2020;35(10):1701-1711.

9. Roy B, Nowak RJ, Roda R, et al. Teleneurology during the COVID-19 pandemic: a step forward in modernizing medical care. J Neurol Sci. 2020;414:116930.

10. Bhaskar S, Bradley S, Chattu VK, et al. Telemedicine across the globe: position paper from the COVID-19 Pandemic Health System Resilience Program (REPROGRAM) international consortium (part 1). Front Public Health. 2020;8:556720.

\section{Manage Your Career | Recruit Top Talent}

The AAN's Neurology Career Center is the largest job site specifically for neurologists. Visit careers.aan.com to find your next hire or search from hundreds of open positions in neurology. 


\section{Neurology}

\section{Global \& Community Health: Implementation of and Patient Satisfaction With the First Neurologic Telemedicine Program in Mexico During COVID-19}

Rogelio Domínguez-Moreno, Miguel García-Grimshaw, Oswaldo Alan Chávez-Martínez, et al.

Neurology 2021;97;293-296 Published Online before print May 27, 2021

DOI 10.1212/WNL.0000000000012291

This information is current as of May 27, 2021

\section{Updated Information \&} Services

References

Subspecialty Collections

Permissions \& Licensing

Reprints including high resolution figures, can be found at: http://n.neurology.org/content/97/6/293.full

This article cites 8 articles, 2 of which you can access for free at: http://n.neurology.org/content/97/6/293.full\#ref-list-1

This article, along with others on similar topics, appears in the following collection(s):

Access to care

http://n.neurology.org/cgi/collection/access_to_care

All Education

http://n.neurology.org/cgi/collection/all_education

All global neurology

http://n.neurology.org/cgi/collection/all_global_neurology COVID-19

http://n.neurology.org/cgi/collection/covid_19

Training-international

http://n.neurology.org/cgi/collection/training_international

Information about reproducing this article in parts (figures,tables) or in its entirety can be found online at:

http://www.neurology.org/about/about_the_journal\#permissions

Information about ordering reprints can be found online:

http://n.neurology.org/subscribers/advertise

Neurology ${ }^{\circledR}$ is the official journal of the American Academy of Neurology. Published continuously since 1951, it is now a weekly with 48 issues per year. Copyright @ 2021 American Academy of Neurology. All rights reserved. Print ISSN: 0028-3878. Online ISSN: 1526-632X.

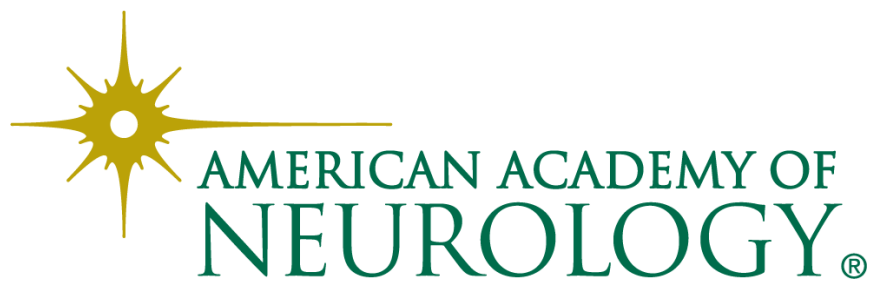

